\title{
Knowledge, attitudes, and behaviors of academics regarding travel- related infections
}

\section{Akademisyenlerin seyahat ilişkili enfeksiyonlar hakkında bilgi, tutum ve davranışları}

\author{
Tugba YANIK YALCIN*1 ${ }^{* 1}$, Mustafa SUNBUL² ${ }^{\text {口, Hakan LE BLEBICIOGLU3 }}$
}

'Baskent University, Faculty of Medicine, Infectious Diseases and Clinical Microbiology, Ankara/TURKEY ${ }^{2}$ Liv Hospital, Infectious Diseases and Clinical Microbiology, Samsun/TURKEY

${ }^{3}$ VM Medicalpark Hospital, Infectious Diseases and Clinical Microbiology, Samsun/TURKEY

\begin{abstract}
Aim: Academics frequently travel to different countries to attend scientific meetings, putting them at risk of contracting serious infectious diseases. We aimed to investigate the knowledge, attitudes and behaviours of academics from Ondokuz Mayıs University regarding travel medicine and pre-travel advice.
\end{abstract}

Material and Methods: We administered a questionnaire consisting of 25 questions to academic staff who travelled abroad. The questionnaire consisted of five sections: demographic information, preparation before travel, events during the travel, events after the travel, and general information about travel health. The chi-square test was used in the statistical assessment of proportional differences, and multivariate analysis was used in the assessment of the effect of independent variables on knowledge of travel health centers.

Results: Two hundred academics participated in the study. Before travelling, 91.5\% of participants reviewed general information about their destination, and $10.5 \%$ received vaccination before travel. Sixty-five participants were familiar with the Directorate General of Health for Border and Coastal Areas of Turkey (DHBC), and $86 \%$ of them were at the Faculty of Medicine, and most of them were male (72\%) ( $p=0.01$ and $p=0.002$, respectively).

Conclusion: Medical doctors' attitudes and knowledge about travel health were higher than those of other faculties. However, this group had a low rate of knowledge that the DHBC provides information about travel health.

Keywords: Travel; infection; travel medicine

Corresponding Author*: Tuğba Yanık Yalçın, Baskent University, Faculty of Medicine, Infectious Diseases and Clinical Microbiology, Ankara/TURKEY E-mail:drtugbayalcin@gmail.com

ORCID: 0000-0001-5996-8639

Recevied: 22.10 .2021 accepted: 11.11 .2021

Doi: $10.18663 /$ tjcl.999275 


\section{Öz}

Amaç: Akademisyenler, bilimsel toplantılara katılmak için sık sık farklı ülkelere seyahat etmektedir. Bu nedenle enfeksiyonlarla karşılaşma riskleri artar. Bu çalışmada Ondokuz Mayıs Üniversitesi'nde görev yapan akademisyenlerin seyahat tıbbı ve seyahat öncesi danışmanlık konusundaki bilgi, tutum ve davranışlarını araştırmayı amaçladık.

Gereç ve Yöntemler: Yurtdışına seyahat eden akademisyenlerden çalışmaya katılmak isteyenlere 25 sorudan oluşan bir anket uygulandı. Anket 5 bölümden oluşmakta idi: 1. demografik bilgiler; 2. seyahat öncesi hazırlık aşamasına yönelik sorular; 3. seyahat sırasında karşılaşılan durumlar; 4. seyahat sonrası gelişebilecek enfeksiyon belirtileri; 5 . seyahat sağlığı ile ilgili genel bilgiler. Orantılı farklııkların istatistiksel değerlendirmesinde ki-kare testi, bağımsız değişkenlerin seyahat sağlık merkezi bilgisine etkisinin değerlendirilmesinde multivaryans analiz kullanılmıştır.

Bulgular: Araştırmaya 200 akademisyen katıldı. Seyahate çıkmadan önce, katılımcıların \%91,5'i gidilecek yerle ilgili genel bilgileri gözden geçirmişti ve \%10,5'i seyahatten önce aşı yaptırmıştı. Altmış beş katılımcı Türkiye Hudut ve Sahiller Sağlık Genel Müdürlüğü'nü (THSGM) biliyordu. THSGM'yi bilenlerin \%86'sı Tıp Fakültesi'ndeydi ve \%72'si erkekti (sırasıyla $p=$ $0.01, p=0.002$ ).

Sonuç:Tıp doktorlarının seyahat sağlığı konusundaki tutum ve bilgi düzeyleri diğer fakültelere göre daha yüksektir. Ancak bu grup dahi THSGM'nin seyahat sağlığı hakkında bilgi sağladığı konusunda yetersiz bilgiye sahiptir.

Anahtar kelimeler: Seyahat; enfeksiyon; seyahat tıbbı

\section{Introduction}

International travel has increased over the last two centuries as a result of technological advancements, increased transportation accessibility, and decreased transportation costs. The increase in travels contributes to the worldwide spread of diseases such as Influenza, Severe acute respiratory syndrome (SARS) virus, Human ımmundeficiency virus (HIV). [1]

In the past 25 years, the concept of "travel medicine" has appeared in the literature and has become a special area of interest for many doctors. Health authorities have also begun to pay attention to the available measures against travelrelated health problems within the framework of national health policies. To contribute to this rapidly developing field, guidelines have been prepared and introduced, such as the Yellow Book and The Practice of Travel Medicine: The Infectious Diseases Society of America (IDSA) Guideline, which are updated annually by the World Health Organization (WHO) and the Centers for Disease Control and Prevention. In addition, organizations have been formed to study travel medicine, such as the International Society of Travel Medicine and the American Society of Tropical Medicine and Hygiene. [1]

The institution that coordinates travel health in Turkey is the Directorate General of Health for Border and Coastal Areas (DHBC). The DHBC staffs 43 travel health clinics across Turkey. Services provided in these centers include pre-travel health examinations, education about health issues that may be encountered during travel, education about prevention of these conditions and medicines that may be required during travel, and administration of necessary vaccinations based on an assessment of the risks prevalent in the region to be traveled. In addition, the "international vaccination certificate," which is required for travelers entering certain countries, is prepared and issued in English, French, and Turkish. [2]

Academics frequently travel abroad for a variety of reasons, including training, attending meetings, and conducting research. As a result, there is a high risk of contracting a travel infection. The aim of this study was to investigate academic personnel at Ondokuz Mayıs University's (OMU) knowledge, behaviours, and attitudes toward travel-related infections.

\section{Material and Methods}

\section{Participant Selection}

This survey study was conducted at Ondokuz Mayıs University. OMU academicians who travelled abroad in 2013 and wanted to answer the survey participated in the study.

\section{Questionnaire}

The questionnaire was divided into five sections and contained a total of 25 questions. The demographic characteristics of the participants (age, gender, comorbidities, regularly used drugs, academic degree, unit they work in) were questioned in the first section. 
The second section questioned the stages of preparation prior to the trip, and the third section asked the infectious diseases they encountered during their travels and their approaches in this situation. There were questions about the post-travel in the fourth section. The fifth section questioned general information about travel health.

\section{Statistical Analysis}

SPSS 15.0 (IBM Inc., Armonk, NY) software system was used for the statistical analyses in the study. Categorical variables were described as number and their percentages. For categorical variables, the chi-square test was used. The logistic regression model with the enter method was used to determine the factors influencing the level of knowledge of DHBC. A p-value of $<0.05$ was accepted as statistically significant.

The study was approved by the ethics committee of Ondokuz Mayıs University. (Project number: 2014/738)

\section{Results}

A total of 270 questionnaires were distributed between October 1 and October 31, 2014; two hundred completed questionnaires were collected. Among the 200 academics who participated in the study, 117 (58.5\%) were male. The median age was 48 years (min.24- max.65). The number of participants who worked at the Faculty of Medicine was 143/200 (71.5\%); 24/200 (12\%) worked at the Faculty of Agriculture; 18 (9\%) worked at the Faculty of Dentistry; $9(4.5 \%)$ at the Faculty of Science and Letters; 5 (2.5\%) at the Faculty of Theology; and 1 $(0.5 \%)$ of the participants worked at the Faculty of Veterinary. A total of 44 (22\%) of the participants had comorbidity. The most common comorbidity was hypertension $26 / 200$ (13\%).

According to the survey results, 307 trips abroad were made in 2013. The number of participants who travelled to more than one country was 105 . The most frequently visited destination was Europe, followed by North America, North Asia, Southwest Asia, East Asia, Africa and South America, respectively (Table 1). The top three countries visited were Italy, Germany and the United States (Figure 1).

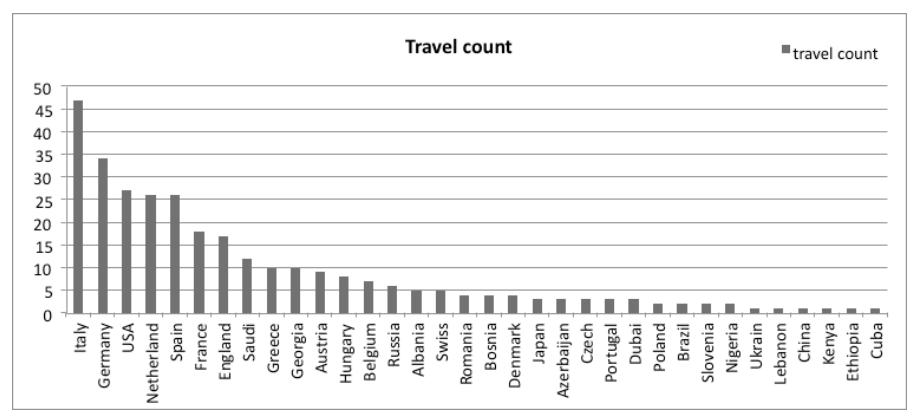

Figure 1. Visited countries and travel count

- 105 people have travelled to multiple countries.

\begin{tabular}{|c|c|}
\hline & Case, n (\%) \\
\hline \multicolumn{2}{|l|}{ Gender } \\
\hline Female & $83(41.5)$ \\
\hline Male & $117(58.5)$ \\
\hline Age, median (min-max) & $48(24-65)$ \\
\hline \multicolumn{2}{|l|}{ Academic degree } \\
\hline Professor & $69(34.5)$ \\
\hline Associate professor & $41(20.5)$ \\
\hline Assistant professor & $34(17)$ \\
\hline Fellow & $7(3.5)$ \\
\hline Research assistant & $43(21.5)$ \\
\hline Doctoral student & $6(3)$ \\
\hline \multicolumn{2}{|l|}{ Faculties } \\
\hline Faculty of medicine & $143(71.5)$ \\
\hline Faculty of agriculture & $24(12)$ \\
\hline Faculty of dentistry & $18(9)$ \\
\hline Faculty of arts and sciences & $9(4.5)$ \\
\hline Faculty of theology & $5(2.5)$ \\
\hline Faculty of veterinary & $1(0.5)$ \\
\hline \multicolumn{2}{|l|}{ Comorbidities } \\
\hline Hypertension & $26(13)$ \\
\hline Diabetes mellitus & $5(2.5)$ \\
\hline COPD - Asthma & $5(2.5)$ \\
\hline Inflammatory bowel disease & $2(1)$ \\
\hline Hypothyroidism & $2(1)$ \\
\hline Coronary artery disease & $2(1)$ \\
\hline Anemia & $1(0.5)$ \\
\hline Hyperlipidemia & $1(0.5)$ \\
\hline \multicolumn{2}{|l|}{ Region of travel* } \\
\hline Europe & 237 \\
\hline North America & 27 \\
\hline North Asia & 16 \\
\hline Southwest Asia & 15 \\
\hline East Asia & 5 \\
\hline Africa & 4 \\
\hline South America & 3 \\
\hline *Travel count & \\
\hline
\end{tabular}

Of the total number of participants, $91.5 \%$ had obtained general information about the place to be visited. There were 147 (73.5\%) participants who said they had extra drugs in their travel packs in addition to the ones they normally carry. The top three most used drugs types were analgesics, antibiotics, and antihistamines.

A total of 24 (12\%) of the participants had an illness during their travel, with a total of 29 infections, because some of them had more than one sickness while travelling ( 5 allergy attacks and a new case of hypertension). There were 11 respiratory tract infections, six diarrhea, six fever, four exanthems, two viral infections, and was a nausea and vomiting. 
The number of people who investigated possible contagious diseases in the regions to which they travelled was 37 (18.5\%), and $23(62.1 \%)$ of them worked at the Faculty of Medicine ( $p=$ $0.041)$. The resources they consulted were the internet $(35.4 \%)$; family and friends (31.2\%); books (10.5\%); travel agencies (10.5\%); community health centres (8.3\%); and family doctors (4.1\%).

The percentage of participants who received pre-travel advice is $10.5 \%$. A total of $21(10.5 \%)$ of the academics were vaccinated before their travel. The vaccines were for meningococci $(n=9)$, influenza $(n=5)$, hepatitis $B(n=3)$, yellow fever $(n=2)$, and 4 of them did not know the content of the vaccination they received. Six participants were given prophylactic antibiotics before the travel. The countries to which these participants travelled were Nigeria, Kenya and Lebanon. The six people who were given prophylactic antibiotics were also among the 21 vaccinated before travel.

The percentage of participants who knew about the travel health centers was $12 \%$, all of whom were doctors ( $p=$ 0.044). No significant relationship was found between having knowledge of travel health centers and gender, the frequency of travel, or having a chronic disease $(p=0.127, p=0.061$ and $p=0.60$, respectively).

The percentage of participants who knew about a website dealing with travel health was $18 \%$, and $86 \%$ of whom were doctors $(p=0.001)$.

The rate of knowledge by academics of a center and a website where they could obtain advanced information about the endemic infectious diseases in the region to be visited are shown in Table 2.

\begin{tabular}{|c|c|c|}
\hline \multicolumn{3}{|c|}{$\begin{array}{l}\text { Table 2. Participants' knowledge rates on travel health } \\
\text { Acquiring knowledge of endemic infectious diseases in the } \\
\text { travel destination region }\end{array}$} \\
\hline & Yes, n (\%) & No, n (\%) \\
\hline Faculty of medicine & $23(\% 16)$ & $120(\% 84)$ \\
\hline Other Faculties & $14(\% 24.5)$ & $43(\% 75.5)$ \\
\hline \multicolumn{3}{|c|}{ Awareness rates about a travel health center } \\
\hline & Yes, n (\%) & No, n (\%) \\
\hline Faculty of medicine & $24(\% 16.7)$ & $119(\% 83.3)$ \\
\hline Other Faculties & 0 & $57(\% 100)$ \\
\hline \multicolumn{3}{|c|}{ Awareness rates about a travel health website } \\
\hline & Yes, n (\%) & No, n (\%) \\
\hline Faculty of medicine & $31(\% 21.6)$ & $112(\% 78.4)$ \\
\hline Other Faculties & $5(\% 8.7)$ & $52(\% 91.2)$ \\
\hline
\end{tabular}

While the number of people who had previously known of the DHBC was 33\% (66/200), the number who knew it provides travel health information and services was only $7.5 \%$ (15/200).
When we proportioned it to all participants, only $7.5 \%$ of participants knew that DHBC provides travel health services. Male gender and status as a medical doctor, among those who had previously heard of DHBC, were statistically significant ( $p$ $=0.01$ and $p=0.002$, respectively). In this case, the odds ratios of being a medical doctor and male gender were 3.433 and 2.184 according to the multivariate analysis conducted to calculate the independent variable (Table 3).

\begin{tabular}{l|c|cc}
\multicolumn{3}{l}{ Table 3. Significant findings in } & multivariate analysis \\
\hline Independent variable & OR & p-value & $\mathrm{Cl} \% 95$ \\
\hline Male gender & 2.184 & $0.018^{*}$ & $1.144-4.170$ \\
\hline Medical doctor & 3.433 & $0.002^{*}$ & $1.555-7.604$ \\
\hline OR: odds ratio; $\mathrm{Cl}$ : confidence interval; * $\mathrm{p}<0.05$ &
\end{tabular}

\section{Discussion}

The knowledge, attitudes, and behaviors of academicians with regarding travel medicine and pre-travel counselling were evaluated in this study. The only institution in our country that is formally permitted to provide travel health services is DHBC. However, it has been observed that even the most socioculturally developed segment of our society lacks adequate information on this subject. The percentage of those who knew that the DHBC provides travel health services $(7.5 \%)$ demonstrates that even the highly-educated segment of the society has insufficient knowledge of this fact.

Various studies conducted all around the world have shown that travel infection risk assessment and health preparation before travel are insufficient. [3] In a survey study conducted among 2,101 people travelling to Asia, Africa, and South America from five airports in Australasia in 2004, it was reported that $31 \%$ of participants received pre-travel health advice. [4] In a different survey conducted with 404 people going to Latin America and Asia from New York's John F. Kennedy International Airport, it was reported that $36 \%$ sought pre-travel consultation. [5] In contrast, the percentage of people who sought pre-travel consultation was $10.5 \%$ in our study. However, the majority of our study participants were visiting Europe, which is thought to be relatively risk-free in terms of exposure to travel-related infections. As a result, our participants may presume they are not required to seek pre-travel advice.

The literature, however, does not support the perception that travelling to Europe is risk-free. In a large-scale study evaluating European travelers, it was reported that travelers encountered many travel infections, such as measles, hepatitis A, typhoid. [6] Another study was reported a hepatitis A outbreak in tourists in Italy. [7] Furthermore, between 2007 and 2012, many dengue 
fever and many chikungunya fever cases were observed in European a study conducted by Tomasello and Schlagenhauf. [8] In our study, 37 of the participants wanted to know about any contagious diseases that might be present in the area they were going to visit before they left. They said $45.9 \%$ of these 37 people got their information from the Internet, $42.8 \%$ from family and friends, $14.2 \%$ from medical books, $14.2 \%$ from a travel agency, $11.4 \%$ from the community health center, and $0.5 \%$ from their family doctors. In comparison, Dahlgren et al. noticed among Swedish residents traveling to areas with risk of malaria and hepatitis, that $60 \%$ of participants had consulted their family doctors, 30\% had visited a travel health center, $26 \%$ had consulted family and friends, and $24 \%$ had searched the Internet. [9]

In addition, 23 of the 37 people in our study who investigated the possibility of contagious diseases in the region they planned to visit were doctors. When people at the Faculty of Medicine were compared to those at other faculties, it was determined that those at the Faculty of Medicine received more information on endemic diseases $(p=0.041)$. As a result of this research, it is hypothesized that doctors are more likely to anticipate the presence of contagious diseases in the region they intend to visit. It is also assumed that because of their greater knowledge of infectious diseases, and these doctors are more motivated than the other academics to take appropriate precautions. However, because of the small number of participants, this result should be interpreted with carefulness.

In this study, being male $(\mathrm{p}=0.01)$ and being a medical doctor $(p=0.002)$ were found to be significant when compared to other variables in terms of known DHBC. As a result of the multivariate analysis conducted, being a medical doctor was three times, and the male gender was two times statistically significant. The academics at the Faculty of Medicine in this study were most likely to know about DHBC more.

The most common travel-related infection is tourist diarrhea and previous studies reported that between $10 \%$ and $60 \%$ of participants experienced. [10] In our study, the percentage of tourists with diarrhea was $20 \%$. In our study, the most common infection was respiratory tract infection. As travels to developed countries are generally made, reaching such a conclusion is one of the possibilities.

More than two million pilgrim candidates from more than 140 countries travel to Mecca, the center of Islam, during each pilgrimage period. [11] The movement of large groups of people increases the risk of contracting contagious diseases. According to one study, the risk of meningococcal disease during the pilgrimage period is $80 \%$ due to overcrowding, high moisture levels, and high levels of air pollution. [12] All study participants who travelled to Saudi Arabia were immunized against meningococcus, as it is a mandatory vaccine.

This study has some limitations, including a small number of study populations and unequal distributions. Because there are more participants from the medical faculty, the results should be interpreted with caution. In addition, the survey responses were self-reported and memory-based. More comprehensive and well-designed studies are required.

\section{Conclusion}

The presenting research found that even the most educated members of society lack adequate knowledge about travelrelated infections and travel health centers. When travelers visit developed countries and the West, they feel safer in terms of the risk of travel-related infections. It is obvious that greater public awareness of the services provided by the DHBC and the Ministry of Health is required. Social media, television, and news media can all be used to raise public awareness and educate the public. Furthermore, the DHBC's inability to operate a sufficient number of travel health centers must be addressed.

\section{Declaration of conflict of interest}

The authors received no financial support for the research and/or authorship of this article. There is no conflict of interest

\section{References}

1. Hill DR, Ericsson CD, Pearson RD, et al. The practice of travel medicine: guidelines by the Infectious Diseases Society of America. Clin Infect Dis 2006; 43:1499-539.

2. T.R. Ministry of Health Turkey Border and Coasts General Directorate of Health travel health centers. http://www. seyahatsagligi.gov.tr/page/merkezler.aspx Access date: 24.12.2014.

3. Hung KK, Lin AK, Cheng CK et al. Travel Health Risk Perceptions and Preparations Among Travelers at Hong Kong International Airport. J. Trav Med 2014; 21: 288-91.

4. Wilder-Smith A, Khairullah NS, Song JH et al. Travel Health Knowledge, Attitudes and Practices among Australasian Travelers. J Travel Med 2004; 11: 9-15.

5. Hamer DH, Connor BA. Travel Health Knowledge, Attitudes and Practices among United States Travelers. JTravel Med 2004; 11:23-26. 
6. Warne B, Weld LH, Cramer JP et al. Travel-Related Infection in European Travelers, EuroTravNet 2011. Journal of Travel Medicine 2014;21: 248-54

7. Severi $E$, Verhoef $L$, Thornton $L$ et al. Large and prolonged food-borne multistate hepatitis A outbreak in Europe associated with consumption of frozen berries, 2013 to 2014. Euro Surveill 2015; 20: 21192.

8. Tomasello D, Schlagenhauf P. Chikungunya and dengue autochthonous cases in Europe, 2007-2012. Travel Med Infect Dis 2013; 11: 274-84

9. Dahlgren A, Deroo L, Steffen R. Prevention of travel-related infectious diseases: knowledge, practices and attitudes of Swedish travellers. Scand J Infect Dis 2006; 38: 1074-80
10. Ryan ET, Kain CK. Health advice and immunizations for travelers. New Engl J Med 2000; 342: 1716-25

11. Ziad AM, Venkatesh S, Qanta AA. Travel epidemiology: the Saudi perspective. Int J Antimic Agents 2003; 21:96-101

12. Al-Gahtani YM, Al-Bushra, Al-Qarawi SM et al. Epidemiological investigation of an outbreak of meningococcal meningitis in Makkah, Saudi Arabia, 1992. Epidemiol Infect 1995; 115: 399-409 